\title{
Financing Firm Innovation in Africa
}

\author{
Michael Asiedu ${ }^{1}$, Sanogo Boubacar ${ }^{1}$, Gabriel Kyeremeh ${ }^{2}$ \\ ${ }^{1}$ School of Finance, Zhongnan University of Economics and Law, Wuhan, China \\ ${ }^{2}$ School of Accounting, Zhongnan University of Economics and Law, Wuhan, China \\ Email: asiedum@stu.zuel.edu.cn, sanogoboubacar2021@gmail.com,cheremeh.gabriel@gmail.com
}

How to cite this paper: Asiedu, M., Boubacar, S., \& Kyeremeh, G. (2021). Financing Firm Innovation in Africa. Modern Economy, 12, 1339-1365. https://doi.org/10.4236/me.2021.129070

Received: August 10, 2021

Accepted: September 19, 2021

Published: September 22, 2021

Copyright (c) 2021 by author(s) and Scientific Research Publishing Inc. This work is licensed under the Creative Commons Attribution International License (CC BY 4.0).

http://creativecommons.org/licenses/by/4.0/ (c) (i) Open Access

\begin{abstract}
This study contributes to the existing literature on innovation by examining how manufacturing firms in Africa fund innovation activities. This study specifically seeks to identify whether innovative companies exhibit financing patterns distinct from those of non-innovative ones. Besides, this study seeks to gauge the association between innovation and firm features, such as ISO certification, firm age, exporter firms, firm size, internal funding, top female manager, top managers' experience, bank financing, obstacle to access to finance, financial constraints, government ownership, and foreign ownership, among others. This study finds that the main drivers of firm innovation in Africa are ISO certification, firm age, firms communicating with customers through emails, and websites, exporter firms, firm size, internal funding, top female manager, top manager's experience, bank financing, trade credit, firm location, and location size. We also found that only $19.6 \%$ of the sampled firms have ISO certification within the last three years. As captured by the innovation index, a summary of the level of innovation among firms shows that only $31.7 \%$ of the firms fall within high innovation. The study, therefore, recommends that to salvage the low levels of firm innovation among African firms, it will be prudent to 1 ) increase $\mathrm{R} \& \mathrm{D}$ spending (the ratio of $\mathrm{R} \& \mathrm{D}$ expenditure to GDP), 2) attract and incentivize highly qualified researchers into public, and privative enterprises, not only into higher institutions of learning, and 3) incentivize and promote patent activities.
\end{abstract}

\section{Keywords}

Firm Financing, Innovation, R \& D, New Technology, New-Product Innovation

\section{Introduction}

Economic theory supported by ample empirical evidence has shown that firms in competitive markets often attain lower levels of research and development $(\mathrm{R}$ 
\& D) investments (Hall, 2002; Hall \& Maffioli, 2008). The reason is that the findings or outcome of an R \& D is non-rivalry in consumption. As much as there is no secrecy about knowledge, the benefits from the R \& D investments will not be totally appropriated by the firm undertaking the investment. The phenomenon will consequently lead to R \& D underinvestment. However, R \& D is not like other investments (Hall, 2002; Hall \& Maffioli, 2008). Wages and salary account for a significant proportion of the $\mathrm{R} \& \mathrm{D}$ investment due to the quality of the human resources involved and therefore raise the possibility of a high degree of losses and uncertainty due to high degrees of failure about the outcome and its economic success.

Various legal and other frameworks such as intellectual property rights (IP), government assistance for $\mathrm{R} \& \mathrm{D}$, tax incentives, and the encouragement of research partnerships have been developed to cushion the underinvestment. The justification for these mitigating interventions is the fact that the social benefits of R \& D outweigh the private benefits; however, the private cost exceeds the social cost. Moreover, financing R \& D activities have become much complicated and create a funding gap when the innovator is different from the financing institution. According to Hall (2002), such funding gaps are because i) the high cost of funding faced by small and new innovative firms is only partially mitigated by venture capital, ii) internal funds are the main source of financing innovation activities by large firms; and, iii) venture capital financing is not a panacea to the financial gap, especially in less developed, and financially repressed countries.

The focus of this study is to add to the existing literature by examining how manufacturing firms fund innovation and R \& D activities in Africa i.e., whether innovative manufacturing firms exhibit financing patterns different from non-innovative manufacturing firms. The study also focuses on measuring the association between firm innovation and firm characteristics such as age, size, male participation in ownership, managers' experience, and financial constraints, among others. The data source is the Enterprise Survey Data 2010 to 2018.

While several research report mixed relationship between R \& D and firm innovation in Africa and other developing nations (Zuniga \& Crespi, 2013), several have documented a positive relationship between $\mathrm{R} \& \mathrm{D}$ and innovation in Asia (Lee \& Kang, 2007; Wang \& Lin, 2013), whereas evidence from Chile and Mexico refutes such findings (Crespi et al., 2011; Zuniga \& Crespi, 2013). For African countries, related findings by Barasa et al. (2017), using data from the enterprise survey data for Kenya, Tanzania, and Uganda, within the period 2010-2012, found that the impacts of firm-level resources on firm innovation vary depending on the institutional environment. They also established the effects of firm-level resources on firm innovation positively moderated by regional institutional quality in the firm operates. Goedhuys (2007) found a positive association between firm product innovation and $\mathrm{R} \& \mathrm{D}$ in Tanzania. A related study (Kamau \& Munandi, 2009) suggested R \& D as a necessary ingredient in the innovation-driven strategy for manufactures in the clothing and textile industry in 


\section{Kenya.}

McGuirk \& Lenihan (2013) highlighted the significant roles of human capital to innovation activities as widely acknowledged as a principal source of innovation. Human capital is made up of formal education and on the job training (Romer, 1990a). Roper \& Love (2006) argued that highly educated and skilled human capital is a direct source of innovation arising through increased absorptive capacity.

A related study in Ghana by Robson et al. (2009) found that firm size and firms involved in exportation had a positive association with innovation, but firm growth was less systematically so. Moreover, firms located in conurbations were much innovative relative to those located in large and small towns

From the above discussion this study identifies the gap in the literature in Africa by examining the obstacles to firm financing and innovation activities. This study argues that access to finance, cost of finance, obstacles to firm finance and some firm characteristics make it difficult for firms to be innovative in Africa. We therefore infer that, the level of innovativeness of a firm is dependent on such factors as financing sourcing sources, obstacles to access to finance, ownership structure and other firm characteristics. We therefore hypothesize that, firm financing sources and constraints affect the level of firm innovation, including top managers experience, ownership structure and other firm characteristics such as firm age, size, use of emails, and websites for communication with customers and suppliers.

\section{Literature Review}

From both theoretical and empirical literature, growth is keenly driven by technological changes that arises from profit-maximizing agents' intentional investment decisions. The distinguishing feature of technology as an input is that it is neither a public good nor conventional good; it is a nonrival, partially excludable good. Price-taking competition cannot be supported because of the nonconvexity introduced by a nonrival good. Instead, the equilibrium is one with monopolistic competition (Romer, 1990b). Therefore, the main conclusions are that the stock of human capital determines the rate of growth, that too little human capital is devoted to research in equilibrium, that integration into world markets will increase growth rates, and that having a large population is not enough to generate growth. Innovation and entrepreneurship levels are associated with better control of corruption and the institutional quality of state and market institutions (Anokhin \& Schulze, 2009). However, without such trust and quality, productivity and investment in innovation are hampered due to high monitoring and other transactions cost of a trade. Highly educated managers, ownership by family association, individuals, or managers, and firm exposure to foreign competition are associated with higher firm innovation (Ayyagari et al., 2011). In addition, access to external firm financing is associated with greater firm innovation in over 19,000 firms across 47 developing economies. It is further indi- 
cated that most of the innovative banks are managed by more educated teams that are diverse with respect to their expertise in their functional areas even after controlling for organizational size, team size, and location (Bantel \& Jackson, 1989). Blundell et al. (1999) reported, positive and robust effect of market share on observable headcounts of patents and innovations, although increased product market competition tends to stimulate innovative activity in the industry. They also reported that firms with higher market shares have their innovation on market value to be larger. Geographical proximity per se is neither a sufficient nor a necessary condition for learning to take place. Nevertheless, it facilitates interactive learning, most likely by strengthening proximity's other dimensions (Boschma, 2005). However, proximity may also have negative impacts on innovation due to the problem of lock-in. Accordingly, too little and regulatory quality, the rule of law, and corruption have strong direct and negative impacts on both firms. The results indicate that the current state of the regulatory quality, the rule of law, and corruption in Russia impede firm innovation and their resulting performance.

In-house R \& D and technology acquisition expenditures have positive payoffs in terms of enhanced probability of introducing new products and processes to the market. In turn, innovators attain higher productivity levels than non-innovators (Chudnovsky et al., 2006). The results also show that large firms have a higher probability of engaging in innovation activities and of becoming innovators. Cooke et al. (1998) argue that work conducted in the "new regional science" field is complementary to systems of innovation approaches. They conclude that an evolutionary approach assists understanding of the regional potential for developing systemic innovation.

Firms with chief executive officers (CEOs) who gain general managerial skills over their work experience lifetime produce more patents (Custódio et al., 2019). That generalist CEOs spur innovation because they acquire knowledge beyond the firm's current technological domain. They possess relevant skills and knowledge that can be utilized elsewhere should innovation projects fail, and an efficient labor market for executives can promote innovation by offering a mechanism of tolerance for failure. In support to existing studies, firms that invest in knowledge are more able to introduce new technological advances and those that innovate have greater labor productivity than those that do not in all countries (Crespi \& Zuniga, 2012). Yet firm-level determinants of innovation investment are much more heterogeneous in OECD countries. Foreign ownership, cooperation and exporting increase the tendency to invest in innovation activities and encourage innovation investment in only half of the countries studied. Scientific and market sources of information have little or no impact on firm innovation efforts, which demonstrates the weak linkages that characterize national innovation systems. After controlling for age and size differences, the findings of the study concludes that some major differences to the extent that small firms use innovative practices, and their connection with new product in- 
troductions (De Jong \& Vermeulen, 2006). Innovation cooperation is recognized as one of its antecedents, together with $\mathrm{R} \& \mathrm{D}$, but with different probable results, depending on the kind of partner. Human capital is claimed to be as essential as other organizational mechanisms for the AC (absorptive capacity) impact on innovation (Franco et al., 2012). Interacting with research organizations, for example, increases the firm's AC providing it occurs within the national boundaries. The transformation of AC into actual innovation is favored by the human firm's and capital while it is hampered by socialization mechanisms of an organizational nature. The option of only depending on internal development is less successful. The findings on firm growth suggest that innovative performance is an essential driver for firm growth. It is particularly the combination of product and process innovations that significantly improve firm growth (Goedhuys \& Veugelers, 2012). Foreign innovative firms have stronger vertical linkages with other foreign firms and invest more in-human and physical capital. Local firms offset these disadvantages through in-house $\mathrm{R} \& \mathrm{D}$, connectivity, and collaboration with other local firms, proving to be more embedded in Tanzania's local industrial structure (Goedhuys, 2007). Jiménez-Jiménez \& Sanz-Valle (2011) argue that organizational culture is a clear determinant of innovation strategy. Moreover, adhocracy cultures foster innovation strategies, and hierarchical cultures promote imitation cultures. The findings show that both variables, organizational learning and innovation have a positive influence on business performance and that organizational learning affects innovation (Laursen et al., 2012). Firms in an area described by a high degree of localized social capital complement firms' investments in internal research and development (R \& D). Such a location positively moderates the effectiveness of externally acquired R \& D on the propensity to innovate. Li \& Atuahene-Gima (2001) found that, innovation-performance link was contingent on environmental factors, including institutional support and, environmental turbulence and the ventures' relationship-based strategies, which includes strategic alliances for political networking and product development in China. In the discourse on product innovation strategy among new ventures, they recommend the need for simultaneous consideration of environment- and relationship-based strategy factors as moderators. According to Liu \& Buck (2007), learning-by-exporting (and importing) enhances innovation within Chinese indigenous firms. Foreign R \& D activities by multinational enterprises in a host country significantly affect domestic firms' innovation performance only when the absorptive ability is taken into account. The innovation capability of a firm depends closely on its intellectual and organizational knowledge assets and on its ability to deploy these assets (Martín-de Castro et al., 2013). They further show the existence of the moderating role of; innovation culture in a knowledge-based product innovation model. Firm-level knowledge factors through knowledge acquisition and assimilation, which is consistent with knowledge sharing linkages and potential absorptive capacity influence innovation implementation when used as mediating factors (McAdam et 
al., 2014). Antecedent factors of lifecycle, culture, leadership, and historical propensity to innovation were found to interact with the mediating variables of knowledge acquisition and assimilation, knowledge sharing linkages (external) and TQM/business improvement to produce a series of innovation outputs, that includes knowledge transformation and sales of new products and services from innovation activities. Robson et al. (2009) found that the extent of a firm's innovation in Ghana was linked to the entrepreneur's education level. Involvement in exporting and firm size exporting had positive relation to innovation, while firm growth was less systematically so. Firms located in conurbations had a greater innovation as compared to firms located in large and small towns. National economic, technological and institutional framework conditions are shown to clearly predict the possibility of firms to engage in innovation (Srholec, 2011).

This article is related to (Barona-Zuluaga et al., 2015; Fernandez, 2017) on the finance of innovation in Latin America but most especially (Robson et al., 2009) but in a more comprehensive sample of 40 African countries and alternative definitions of firm innovation. The remainder of the paper is organized as follows. Section 2 presents figures on innovation in Africa, low-income countries, and some selected high-income countries to provide some background information. The data and some descriptive statistics are presented in Section 3. Section 4 also presents the estimation process and the empirical results. Section 5 will present the main findings and policy recommendations.

\section{Some Figures on $\mathbf{R} \&$ D Expenditure in Africa and the World}

The World Development Indicators on Science and Technology indicators, we gathered we gathered information on science and technology indicators of low \& middle-income countries, some African countries based on data availability, and some developed countries (U.S \& UK) for the period 2000 to 2018. For illustration purposes, Figures 1-3, respectively, depict the share of GDP on R \& D, FTE per million (Highly-qualified human capital) labor force from 2000-201, and Patent applications per residents.

The figures below reflect how much-limited resources allocation is made to $\mathrm{R}$ \& D in Africa and low \& middle-income countries as compared to the US, UK and China (Figure 1). It is evident from Figure 1 that most African and low and middle-income countries between the period 2000 to 2015 have averagely spent less than $1 \%$ of their annual incomes on R \& D. For instance, Madagascar has, on average, spent less than $0.5 \%$ of its annual income on $\mathrm{R} \& \mathrm{D}$ whilst the US and UK have spent nearly $2.7 \%$ and $1.8 \%$ of their annual income on R \& D for the same period. Whilst the US national average of $2.7 \%$ is above the worlds average share expenditure of $2 \%$, the shares of annual expenditure on $\mathrm{R} \& \mathrm{D}$ by African countries (e.g. Uganda, Madagascar, Burkina Faso, South Africa etc.) and the average share by low \& middle-income countries do not only trail the 


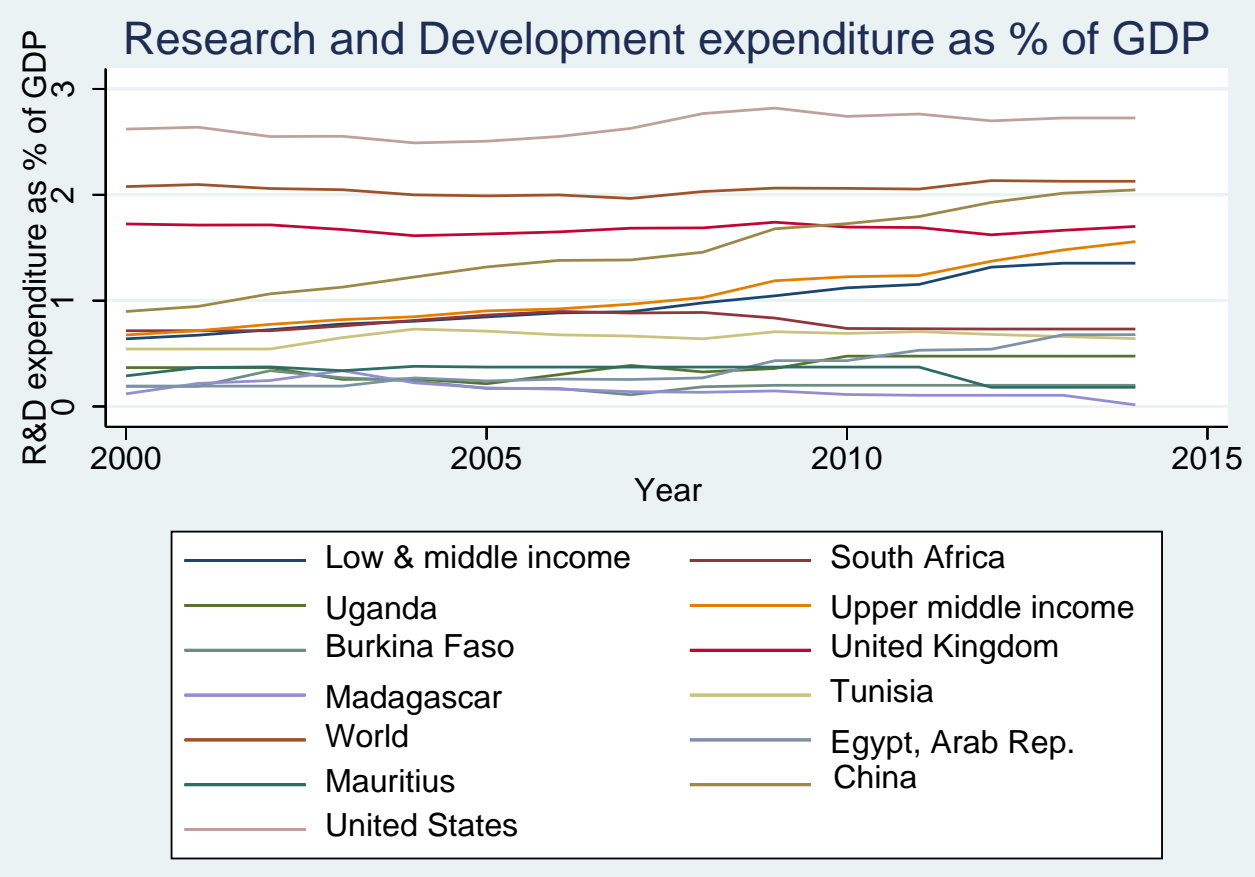

Figure 1. R \& D expenditure as \% of GDP.

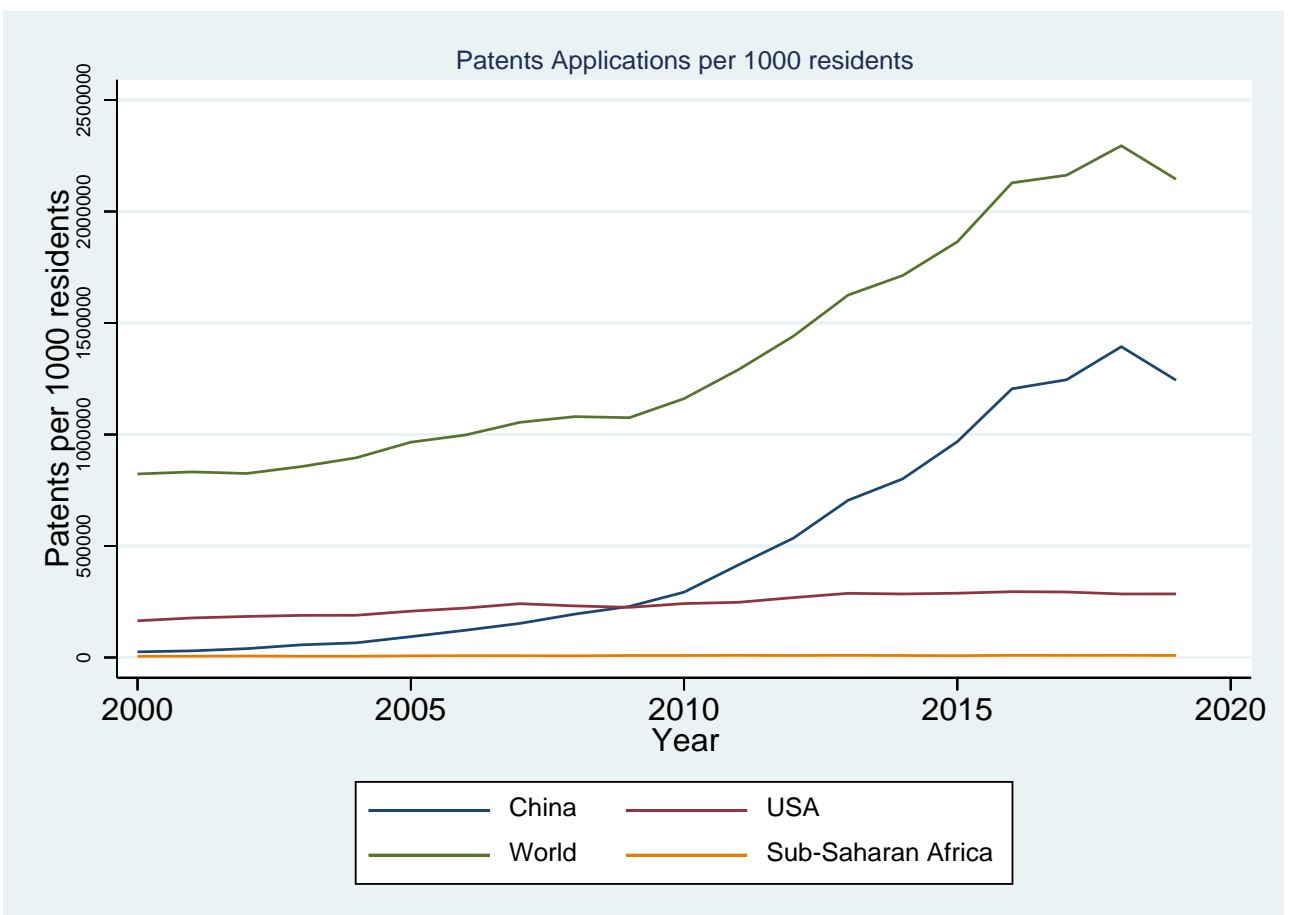

Figure 2. Patents application per 1000 residents.

US by far but also the World average share. We further present the number of full-time equivalence (FTE) researchers per million population for the countries in Sub-Sahara Africa, the U.S, and the World for the period 2000-2019 since R \& $\mathrm{D}$ requires highly specialized human capital. This relation is illustrated in Figure 
3. Specifically, the number of FTE per million population increased steadily in the US from 3135 per 1000 labor force in 1996 to 4256 per 1000 labor force in 2017, far above the world average since 2000. Meanwhile, in Sub-Sahara Africa, the indicator rose from 47 per million population in the year 2000 to a little 1000 million population in 2019. In Figure 2, the study presents the number of patent application per 1000 residents. We show that the number of patents applications in the entire Sub-Saharan Africa is significantly less compared to China and the US.

\section{Data}

The main data source of this study is the World Bank's Enterprise Surveys Indicator Database, https://www.enterprisesurveys.org. We constructed a pooled cross-sectional data for 40 countries from 2010 to 2018 in Africa since there is no Panel Data Enterprise Surveys Indicator Database.

\section{Full Data for Selected Countries}

From the World Bank's Enterprise Survey Indicator Database, we selected 40 African countries from the period 2010 to 2018. Details of the specific countries and the number of observations for each country are provided in Table 1. The descriptive statistics for a set of variables regarding firm characteristics, financing sources, and the use of technology are provided in Table 2. Except for the firm's-age and top managers' experience, all other variables are either dummies, taking values of 0 and 1 , or measured in percentages. From the descriptive statistic

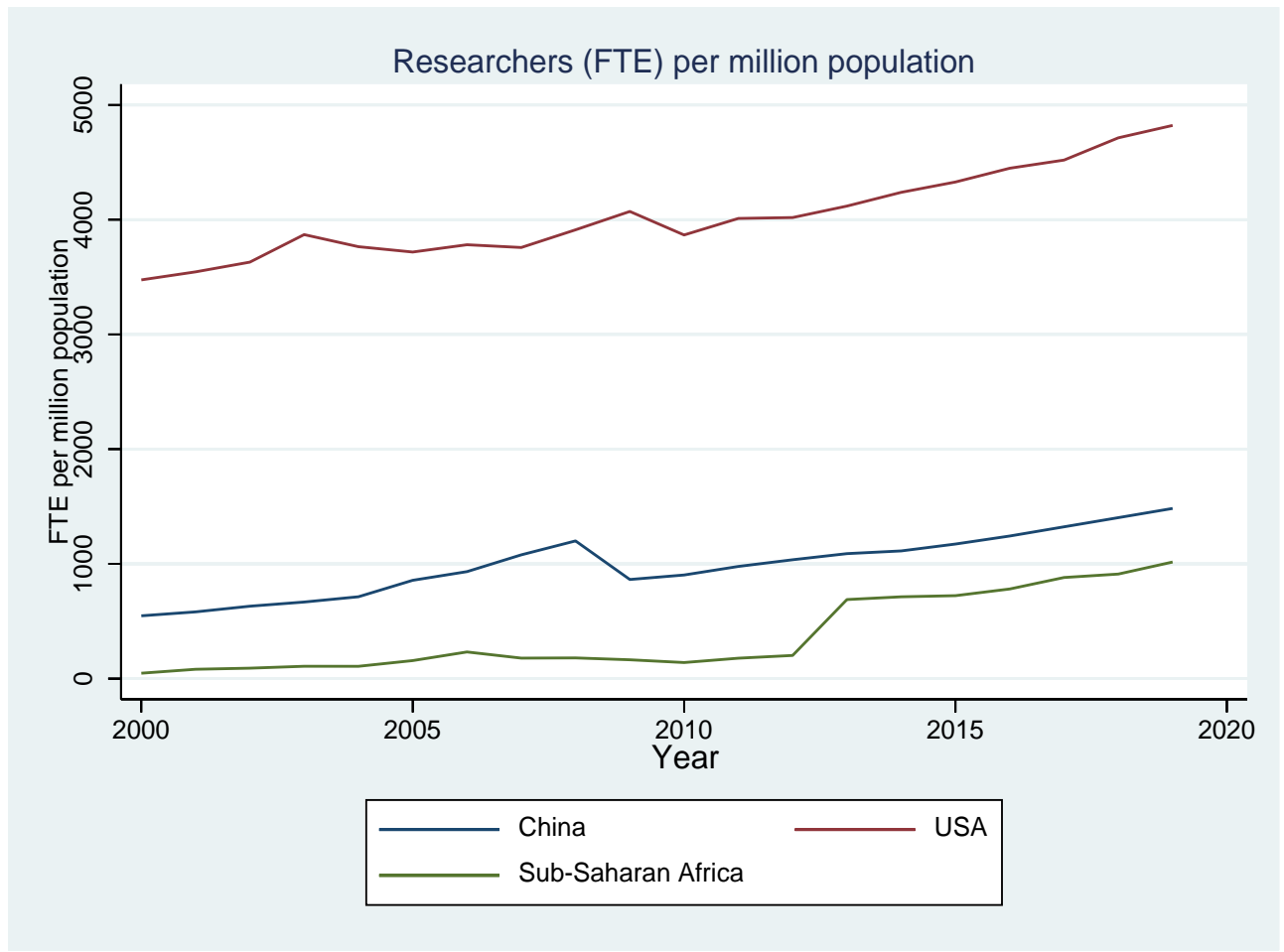

Figure 3. Researchers (FTE) per million population. 
Table 1. Tabulation of country.

\begin{tabular}{|c|c|c|c|}
\hline & Freq. & Percent & Cum. \\
\hline South Sudan & 738 & 3.59 & 3.59 \\
\hline Angola & 360 & 1.75 & 5.34 \\
\hline Benin & 150 & 0.73 & 6.06 \\
\hline Botswana & 268 & 1.30 & 7.37 \\
\hline Burkina Faso & 394 & 1.91 & 9.28 \\
\hline Burundi & 157 & 0.76 & 10.04 \\
\hline Cameroon & 361 & 1.75 & 11.80 \\
\hline Central African Republic & 150 & 0.73 & 12.53 \\
\hline Chad & 153 & 0.74 & 13.27 \\
\hline Ivory Coast & 361 & 1.75 & 15.02 \\
\hline DRC & 529 & 2.57 & 17.59 \\
\hline Djibouti & 266 & 1.29 & 18.89 \\
\hline Egypt & 2,897 & 14.08 & 32.96 \\
\hline Ethiopia & 644 & 3.13 & 36.09 \\
\hline Gabon & 179 & 0.87 & 36.96 \\
\hline Gambia & 151 & 0.73 & 37.70 \\
\hline Ghana & 720 & 3.50 & 41.20 \\
\hline Guinea & 150 & 0.73 & 41.92 \\
\hline Kenya & 781 & 3.79 & 45.72 \\
\hline Lesotho & 150 & 0.73 & 46.45 \\
\hline Liberia & 151 & 0.73 & 47.18 \\
\hline Malawi & 523 & 2.54 & 49.72 \\
\hline Mali & 185 & 0.90 & 50.62 \\
\hline Mauritania & 150 & 0.73 & 51.35 \\
\hline Morocco & 407 & 1.98 & 53.33 \\
\hline Mozambique & 601 & 2.92 & 56.25 \\
\hline Namibia & 580 & 2.82 & 59.07 \\
\hline Niger & 151 & 0.73 & 59.80 \\
\hline Nigeria & 2676 & 13.00 & 72.80 \\
\hline Republic of South Africa & 1057 & 5.14 & 77.94 \\
\hline Senegal & 601 & 2.92 & 80.86 \\
\hline Sierra Leone & 152 & 0.74 & 81.60 \\
\hline Swaziland & 150 & 0.73 & 82.33 \\
\hline Tanzania & 813 & 3.95 & 86.28 \\
\hline Togo & 150 & 0.73 & 87.01 \\
\hline Tunisia & 592 & 2.88 & 89.88 \\
\hline
\end{tabular}




\section{Continued}

\begin{tabular}{cccc}
\hline Uganda & 762 & 3.70 & 93.59 \\
Zambia & 720 & 3.50 & 97.08 \\
Zimbabwe & 600 & 2.92 & 100.00 \\
Total & 20,580 & 100.00 & \\
\hline
\end{tabular}

Note! Table 1 above gives account of the total number of firms of each country under consideration. The total number of countries in the sample is 39. The country with the highest number of firms is Egypt (2897 firms), followed closely by Nigeria (2676 firms). For the countries with the lowest representation in the sample, Swaziland, Togo, Lesotho, Guinea, Mauritania, Central Africa Republic, and Benin have equal representation of 150 firms.

Table 2. Descriptive statistics of selected Africa countries.

\begin{tabular}{|c|c|c|c|c|c|}
\hline Variable & Obs & Mean & Std. Dev. & Min & $\operatorname{Max}$ \\
\hline New product & 20,580 & 0.492 & 0.5 & 0 & 1 \\
\hline New technology & 20,580 & 0.392 & 0.488 & 0 & 1 \\
\hline Index & 20,580 & 1.932 & 0.75 & 1 & 3 \\
\hline Exporter & 20,529 & 6.993 & 20.259 & 0 & 100 \\
\hline Email & 20,580 & 0.61 & 0.488 & 0 & 1 \\
\hline Website & 20,580 & 0.386 & 0.487 & 0 & 1 \\
\hline ISO & 20,580 & 0.196 & 0.397 & 0 & 1 \\
\hline Top Manager F. & 20,580 & 0.114 & 0.318 & 0 & 1 \\
\hline Top Manager E. & 20,554 & 16.288 & 11.012 & 0 & 72 \\
\hline Firm Age & 20,576 & 21.745 & 14.324 & 1 & 172 \\
\hline Internal funds & 20,555 & 75.983 & 32.081 & 0 & 100 \\
\hline B. from Banks & 16,093 & 9.355 & 20.921 & 0 & 100 \\
\hline B. from N.Banks & 20,555 & 2.826 & 11.051 & 0 & 100 \\
\hline Trade Credit & 20,555 & 9.567 & 19.355 & 0 & 100 \\
\hline Firm Size & 20,580 & 2.419 & 0.726 & 1 & 3 \\
\hline Obstacle to Fund & 20,555 & 2.902 & 1.336 & 1 & 5 \\
\hline MMs11 & 20,580 & 0.888 & 0.315 & 0 & 1 \\
\hline$\%$ Private/domes. & 20,580 & 81.307 & 35.623 & 0 & 100 \\
\hline \%Foreign owned & 20,579 & 12.579 & 30.003 & 0 & 100 \\
\hline \%Government & 20,579 & 1.608 & 8.736 & 0 & 100 \\
\hline
\end{tabular}

The data source is the Enterprise Survey Indicator Database.

table, the mean age of a firm is 21.745 , and the mean experience of a top manager is 16.288 . Whilst the oldest firm is 172 years, the manager with the most experience is 72 years of experience.

In Table 3, we report the relationship between firm size and their location. The study finds that most firms are sparsely distributed across geographical locations. However, most small and large firms are located in towns with a 50,000 population. In Table 4, we present the relationship between firm size and the 
Table 3. Firm size versus Firm location.

\begin{tabular}{cccccccc}
\hline $\begin{array}{c}\text { Size (Number of } \\
\text { employees) }\end{array}$ & $\begin{array}{c}\mathbf{5 0 , 0 0 0} \text { to } \\
\mathbf{2 5 0 , 0 0 0}\end{array}$ & $\begin{array}{c}\text { Capital } \\
\text { City }\end{array}$ & $\begin{array}{c}\text { Over } \mathbf{2 5 0 , 0 0 0} \\
\text { to } \mathbf{3} \text { million }\end{array}$ & $\begin{array}{c}\text { Only } \\
\text { Regional } \\
\text { capital }\end{array}$ & $\begin{array}{c}\text { Less than } \\
\mathbf{5 0 , 0 0 0}\end{array}$ & $\begin{array}{c}\text { Over } \\
\mathbf{2 5 0 , 0 0 0} \text { to } \\
\mathbf{1 m i l l i o n}\end{array}$ & Total \\
\hline $\begin{array}{c}\text { Large } \\
\%\end{array}$ & 208 & 451 & 5 & 196 & 1,437 & 629 & 2926 \\
Medium & 10.92 & 18.14 & 14.71 & 18.54 & 15.09 & 11.29 & 14.22 \\
$\%$ & 479 & 790 & 7 & 366 & 2827 & 1645 & 6,114 \\
Small & 25.14 & 31.78 & 20.59 & 34.63 & 29.68 & 29.52 & 29.71 \\
$\%$ & 1218 & 1245 & 22 & 495 & 5262 & 3298 & 11,540 \\
Total & 63.94 & 50.08 & 64.71 & 46.83 & 55.24 & 59.19 & 56.07 \\
$\%$ & 1905 & 2486 & 34 & 1057 & 9526 & 5572 & 20,580 \\
\hline & 100.00 & 100.00 & 100.00 & 100.00 & 100.00 & 100.00 & 100.00 \\
\hline
\end{tabular}

Pearson chi2 $(10)=184.9653, \mathrm{Pr}=0.000$, Cramer's V $=0.0670$. Notes: 1 ) Pearson's chi-squared statistic is computed for the hypothesis that the rows and columns in a two-way table are independent. 2) Cramer's V is a measure of association between two nominal variables, giving a value between 0 and 1 . It is based on Pearson's chi-squared statistic.

Table 4. Firm size versus level of obstacle to access to finance.

\begin{tabular}{ccccccc}
\hline $\begin{array}{c}\text { Size (number of } \\
\text { employees) }\end{array}$ & $\begin{array}{c}\text { Minor } \\
\text { obstacle }\end{array}$ & $\begin{array}{c}\text { Moderate } \\
\text { obstacle }\end{array}$ & $\begin{array}{c}\text { No } \\
\text { obstacle }\end{array}$ & $\begin{array}{c}\text { Major } \\
\text { obstacle }\end{array}$ & $\begin{array}{c}\text { Very severe } \\
\text { obstacle }\end{array}$ & Total \\
\hline Large & 563 & 603 & 950 & 517 & 286 & 2919 \\
$\%$ & 13.31 & 15.37 & 19.58 & 10.96 & 10.11 & 14.20 \\
Medium & 1222 & 1264 & 1622 & 1273 & 720 & 6101 \\
$\%$ & 28.88 & 32.21 & 33.42 & 26.99 & 25.44 & 29.68 \\
Small & 2446 & 2057 & 2281 & 2927 & 1824 & 11,535 \\
$\%$ & 57.81 & 52.42 & 47.00 & 62.05 & 64.45 & 56.12 \\
Total & 4231 & 3924 & 4853 & 4717 & 2830 & 20,555 \\
& 100.00 & 100.00 & 100.00 & 100.00 & 100.00 & 100.00 \\
\hline
\end{tabular}

Pearson chi2 $(8)=382.3024, \mathrm{Pr}=0.000$, Cramer's V $=0.0964$. Notes: 1 ) Pearson's chi-squared statistic is computed for the hypothesis that the rows and columns in a two-way table are independent. 2) Cramer's $\mathrm{V}$ is a measure of association between two nominal variables, giving a value between 0 and 1 . It is based on Pearson's chi-squared statistic.

level of an obstacle to finance. Small firms are reported to face a severe obstacle to accessing finance. In fact, $64.45 \%$ of the firms facing very severe obstacles to financing are small firms. From Table 5, the study reports the relationship between firm size and the introduction of significantly improved products (new products). The study reports no positive association between firm size and the introduction of new products. We, however, that $52.14 \%$ of firms introducing new products are small firms. In Table 6, the study presents the relationship between firm size and firms with ISO certification. We find that $34.49 \%$ of the firms with ISO international certification are medium-size firms.

Meanwhile, $33.92 \%$ of the firm with ISO international certification are large firms. The relationship between firm size and top female managers is reported in 
Table 5. Firm size versus New product.

\begin{tabular}{cccc}
\hline Size (number of employees) & No & Yes & Total \\
\hline Large & 1250 & 1676 & 2926 \\
$\%$ & 11.96 & 16.55 & 14.22 \\
Medium & 2942 & 3172 & 6114 \\
$\%$ & 28.15 & 31.32 & 29.71 \\
Small & 6259 & 5281 & 11,540 \\
$\%$ & 59.89 & 52.14 & 56.07 \\
Total & 10,451 & 10,129 & 20,580 \\
$\%$ & 100.00 & 100.00 & 100.00 \\
\hline
\end{tabular}

Pearson chi2 $(2)=148.5566, \mathrm{Pr}=0.000$ Cramer's V $=0.0850$. Notes: 1) Pearson's chi-squared statistic is computed for the hypothesis that the rows and columns in a two-way table are independent. 2) Cramer's V is a measure of association between two nominal variables, giving a value between 0 and 1 . It is based on Pearson's chi-squared statistic.

Table 6. Firm size versus ISO certification.

\begin{tabular}{cccc}
\hline Size (number of employees) & No & Yes & Total \\
\hline Large & 1556 & 1370 & 2926 \\
Medium & 9.41 & 33.92 & 14.22 \\
$\%$ & 4725 & 1389 & 6114 \\
Small & 28.57 & 34.39 & 29.71 \\
$\%$ & 10,260 & 1280 & 11,540 \\
Total & 62.03 & 31.69 & 56.07 \\
& 16,541 & 4039 & 20,580 \\
\hline
\end{tabular}

Pearson chi2 $(2)=1.9 \mathrm{e}+03 \mathrm{Pr}=0.000$; Cramer's V $=0.3072$. Notes: 1 ) Pearson's chi-squared statistic is computed for the hypothesis that the rows and columns in a two-way table are independent. 2) Cramer's $\mathrm{V}$ is a measure of association between two nominal variables, giving a value between 0 and 1 . It is based on Pearson's chi-squared statistic.

Table 7. We find that $67.39 \%$ of top female managers are in small firms, whiles only $8.01 \%$ of the top manager female managers are in large firms. From Table 8 , we find that $48.53 \%$ of the firms that introduced significantly new technology are small firms. Only $18.05 \%$ of the firms that introduced significantly new technology are large firms.

\section{Methodology}

The empirical analysis of this study is developed on the latent regression of the form:

$$
y^{*}=x^{\prime} \beta+\varepsilon
$$

where $y^{*}$ is an unobservable index variable, $x$ is a vector of explanatory variables, $\beta$ is a vector of parameters, and $\varepsilon$ is an error term (see, for instance, 
Table 7. Firm size versus Top manager female.

\begin{tabular}{cccc}
\hline Size (Number of employees) & No & Yes & Total \\
\hline Large & 2738 & 188 & 2926 \\
$\%$ & 15.02 & 8.01 & 14.22 \\
Medium & 5537 & 577 & 6114 \\
$\%$ & 30.37 & 24.60 & 29.71 \\
Small & 9959 & 1581 & 11,540 \\
$\%$ & 54.62 & 67.39 & 56.07 \\
Total & 18,234 & 2346 & 20,580 \\
& 100.00 & 100.00 & 100.00 \\
\hline
\end{tabular}

Pearson chi2 $(2)=155.4687 \mathrm{Pr}=0.000$; Cramer's V $=0.0869$. Notes: 1 ) Pearson's chi-squared statistic is computed for the hypothesis that the rows and columns in a two-way table are independent. 2) Cramer's V is a measure of association between two nominal variables, giving a value between 0 and 1 . It is based on Pearson's chi-squared statistic.

Table 8. Firm size versus New technology.

\begin{tabular}{cccc}
\hline Size (employees) & No & Yes & Total \\
\hline Large & 1470 & 1456 & 2926 \\
$\%$ & 11.75 & 18.05 & 14.22 \\
Medium & 3417 & 2697 & 6114 \\
$\%$ & 27.31 & 33.43 & 29.71 \\
Small & 7625 & 3915 & 11,540 \\
$\%$ & 60.94 & 48.53 & 56.07 \\
Total & 12,512 & 8068 & 20,580 \\
& 100.00 & 100.00 & 100.00 \\
\hline
\end{tabular}

Pearson chi2 (2) = 333.5093 Pr $=0.000$; Cramer's V = 0.1273. Notes: 1 ) Pearson's chi-squared statistic is computed for the hypothesis that the rows and columns in a two-way table are independent. 2) Cramer's $\mathrm{V}$ is a measure of association between two nominal variables, giving a value between 0 and 1 . It is based on Pearson's chi-squared statistic.

Liu, 2015, chap. 3 and 11).

For the binary case (Section 4.1), $y=1$ (i.e., innovative firm) if $y^{*}>0$ and $y=0$ (i.e., non-innovative firm) if $y^{*} \leq 0$. For the ordered case where $y$ denotes a firm innovation level, which ranges from 1 to $J$.

$y=1$ if $y^{*} \leq \alpha_{1}, y=2$ if $\alpha_{1}<y^{*} \leq \alpha_{2}, \cdots, y=J$ if $\alpha_{J-1} \leq y^{*}$ such that $\alpha_{1}<\alpha_{2}<\cdots<\alpha_{J-1}$ are the threshold parameters or cutoffs.

For binary data, the odds ratio of a logit model is given by

$$
\frac{p}{1-p}=\frac{1+\mathrm{e}^{\mathrm{x} / \beta}}{1+\mathrm{e}^{-x / \beta}}=\mathrm{e}^{x / \beta}
$$

The odds ratio represents the probability of success or having an event, $p$, to the probability of failure or not having an event $(1-p)$.

By taking natural logarithm of both sides of Equation (2), one obtains the lo- 
gistic regression model

$$
\ln \left(\frac{p}{1-p}\right)=x^{\prime} \beta=\beta_{1}+\beta_{2} x_{2}+\cdots+\beta_{k} x_{k}
$$

For the ordered model $\operatorname{Pr}(y<j) \equiv P_{j}=\operatorname{Pr}\left(x^{\prime} \beta+\varepsilon<\alpha_{j}\right)=\operatorname{Pr}\left(\varepsilon<\alpha_{j}-x^{\prime} \beta\right)$ so that the odds of being at or below category $j$ is given by

$$
\frac{p}{1-p}=\frac{1+\mathrm{e}^{\alpha_{j}-x^{\prime} \beta}}{1+\mathrm{e}^{-\left(\alpha_{j}-x^{\prime} \beta\right)}}=\mathrm{e}^{\alpha_{j}-x^{\prime} \beta}, J=1, \cdots,(J-1)
$$

and the ordinal logistic regression can be represented by

$$
\ln \left(\frac{p_{j}}{1-p_{j}}\right)=\alpha_{j}-x^{\prime} \beta=\alpha_{j}-\left(\beta_{1}+\beta_{2} x_{2}+\cdots+\beta_{k} x_{k}\right), J=1, \cdots,(J-1)
$$

\section{Innovation as a Binary and Ordered Variable}

Following Verdier et al. (2010) and Barona-Zuluaga et al. (2015), we adopt Innovation as either a New Product or New Technology or one of the two aggregate indicators (Index). The enterprise survey asks a set of questions as to whether particular firms engaged in specific innovative activities; including questions on the amount of resources invested in R \& D. This study, however, limits the questions on the firm's innovation activities to Innovation is either New Product or New Technology since all the other question are mainly innovation activities outside the invention of new products. Also following Ayyagari \& Maksimovic (2007), who argued that innovation in countries located far inside their production possibility frontier might mostly be imitating and adopting instead of inventing.

Most importantly, we acknowledge that our sample consists of only African countries that are predominantly less developed economies and are most likely operating within their frontier. In addition, Gorodnichenko et al. (2010) argued that using $\mathrm{R} \& \mathrm{D}$ expenditure as a basis of innovation may be inappropriate. Their reason is that not all innovations are generated by $\mathrm{R} \& \mathrm{D}$ expenditures, and formal R \& D measures are typically biased against small firms. Again, following Ayyagari \& Maksimovic (2007), we constructed an ordered innovation variable (Index). The measure Index is an aggregate obtained by summing new product and new technology. Both innovations in new products and new technology are dummy variables that take the value of one if the answer is positive and zero if the answer is negative.

The descriptive statistic and measure of association between firm size and the ordered innovation category (Index) is presented in Table 9. It is shown that $43.31 \%$ of the sampled firms fall into the Low innovation category, whilst the remaining are $31.73 \%$ and $24.95 \%$ for high innovation and medium innovation respectively. The estimation of the binary and ordered models is reported for the three dependent variables: New product, New technology and Index in Tables 10-12. The explanatory variables are Exporter: exporter \% (exporter vs. 
Table 9. Firm size versus Innovation (Index) level.

\begin{tabular}{ccccc}
\hline Size (employees) & High & Low & Medium & Total \\
\hline Large & 1199 & 993 & 734 & 2926 \\
$\%$ & 18.36 & 11.14 & 14.29 & 14.22 \\
Medium & 2194 & 2439 & 1481 & 6114 \\
$\%$ & 33.59 & 27.36 & 28.84 & 29.71 \\
Small & 3138 & 5482 & 2920 & 11,540 \\
$\%$ & 48.05 & 61.50 & 56.86 & 56.07 \\
Total & 6531 & 8914 & 5135 & 20,580 \\
& 100.00 & 100.00 & 100.00 & 100.00 \\
\hline
\end{tabular}

Pearson chi2 $(4)=311.5797 \mathrm{Pr}=0.000$; Cramer's V $=0.0870$. Notes: 1 ) Pearson's chi-squared statistic is computed for the hypothesis that the rows and columns in a two-way table are independent. 2) Cramer's V is a measure of association between two nominal variables, giving a value between 0 and 1 . It is based on Pearson's chi-squared statistic.

non-exporters); Email is a dummy indicating whether the firm uses email, website is a dummy indicating whether the firm has a website for its operations, ISO is a dummy indicating whether the has an ISO certification, Top Manager female is a dummy indicating whether the top manager is female, Top Manager experience, natural logarithm of firm age, Private-domestic ownership (\%); Internal funds: internal funds for investment (\%); Borrowed from banks: bank finance for investment (\%); Borrowed from non-bank financial: non-bank financial institutions finance for investment (\%); Purchases on credit from supplier: supplier credit financing (\%); Firm Size (1: small, 2: medium and 3: large) Obstacle to fund: access to finance obstacle (1: No obstacle; 2: Minor obstacle; 3 : Moderate obstacle; 4: Major obstacle; 5: Very severe obstacle); MMs11 is a dummy indicating whether the firms uses mobile money for transactions; Foreign ownership: foreign ownership share (\%); Government ownership: share of government ownership share (\%)

Variable definitions are as follows: Exporter: (exporter vs. non-exporters); Email: firms with email address; website: firms with website; ISO: firms with ISO certification; Top Manager female: firms with female top managers; Top Manager experience: top managers experience (years); Firm Age: firm's age (years); Private-domestic ownership (\%); Internal funds: internal funds for investment (\%); Borrowed from banks: bank finance for investment (\%); Borrowed from non-bank financial: non-bank financial institutions finance for investment (\%); Purchases on credit from suppliers: supplier credit financing (\%); Size number of employees codes: firm size (number of employees); Obstacle to fund: obstacle to finance; MMs11: firms using mobile money for transactions; Foreign ownership: foreign ownership share (\%); Government ownership: share of government ownership share (\%).

From the binary logit model with new product as the dependent variable, the estimation results show that email, website, ISO, firm age, supply credit, MMs1 
and firm location have positive and significant impact on firm innovation (new product). However, we also found that variables as exporter, top managers experience, internal funds, funding from non-banks, and government share of ownership negatively impacts new product innovation. For instance, the odds of being a new product innovative firm increases by 1.4 when natural logarithm of age increases by 1 unit (i.e., a 2.8-year increase in firm age). Similarly, the odds of being a product innovative firm decreases by 0.992 when then share of government ownership increases by 1 unit (i.e., a 1.98 decrease in government ownership). Interestingly, foreign ownership and obstacle to access to finance is found to have no significant association to new product innovation.

From Table 10, the dependent variable is New Product (a dummy variable that takes the value 1 if the firm has introduced new product that is substantially different on the market in the last three years). The independent variables are Exporter, Email, Website, ISO certification, top Female Manager, Mobile money usage (MMs1) are all dummy variables that take the value 1 if the firm responded yes), Firm age, top managers experience. Obstacles to access to firm finance, firm size are ordered variables. \% of internal funding, \% of Purchase credit, \% of borrowing from banks, $\%$ of borrowing from non-bank, $\%$ of government ownership, \% foreign ownership, \% private domestic ownership.

From the binary logit model with new technology as the dependent variable the estimation results show that email, website, ISO, firm age, supply credit, MMs1, private domestic ownership, foreign ownership, firm industry, and firm location have positive and significant impact on firm innovation (new product). However, we also found that variables such as exporter, top manager's experience, top female manager, internal funds, funding from non-banks, firm size and government share of ownership negatively impact new product innovation. For instance, the odds of being a new product innovative firm increases by 1.62 when natural logarithm of age increases by 1 unit (i.e., a 3.24-year increase in firm age). Similarly, the odds of being a product innovative firm decreases by 0.993 when then share of government ownership increases by 1 unit (i.e., a 1.99 decrease in government ownership). We also record those higher levels of financial barriers (i.e., finance as an obstacle) have no significant association with new technology innovation. The study also finds that while foreign ownership is a positive and significant determinant of firm innovation (Index), obstacle to access to firm finance is not significantly associated with innovation. However, this finding is in sharp contrast to the conclusions of Lee, Sameen, and Cowling (2015) for medium-sized enterprises waves data in the UK for the periods 2007 2008,2010 , and 2012, that innovative firms have less chances of getting access to finance than other firms.

From Table 11, the dependent variable is New Technology (a dummy variable that takes the value 1 if the firm has introduced new technology that has substantially changed the way the main product is produced in the last three years). The independent variables are Exporter, Email, Website, ISO certification, 
Table 10. Regression results for significantly improved products.

\begin{tabular}{|c|c|c|c|}
\hline New product & Coefficient & Odds Ratio & $\mathrm{dy} / \mathrm{dx}$ \\
\hline \multirow[t]{2}{*}{ Exporter } & $-0.003^{* * *}$ & $1.000^{* * *}$ & $-0.001^{* * *}$ \\
\hline & $(0.001)$ & $(0.001)$ & $(0.000)$ \\
\hline \multirow[t]{2}{*}{ Email } & $0.348^{\star * *}$ & $1.416^{\star * *}$ & $0.085^{\star * *}$ \\
\hline & $(0.041)$ & $(0.058)$ & $(0.010)$ \\
\hline \multirow[t]{2}{*}{ Website } & $0.697^{\star * *}$ & $2.009^{* * *}$ & $0.170^{* * *}$ \\
\hline & $(0.045)$ & $(0.090)$ & $(0.011)$ \\
\hline \multirow[t]{2}{*}{ ISO } & $0.507^{\star * *}$ & $1.660^{* * *}$ & $0.124^{\star * *}$ \\
\hline & $(0.050)$ & $(0.082)$ & $(0.012)$ \\
\hline \multirow[t]{2}{*}{ Top Manager female } & -0.069 & 0.933 & -0.017 \\
\hline & $(0.052)$ & $(0.048)$ & $(0.013)$ \\
\hline \multirow[t]{2}{*}{ Top Manager exp. } & $-0.012^{* * *}$ & $0.988^{\star * *}$ & $-0.003^{* * *}$ \\
\hline & $(0.002)$ & $(0.002)$ & $(0.000)$ \\
\hline \multirow[t]{2}{*}{ Ln (Firm Age) } & $0.317^{\star * *}$ & $1.373^{* * *}$ & $0.077^{\star * *}$ \\
\hline & $(0.034)$ & $(0.046)$ & $(0.008)$ \\
\hline \multirow[t]{2}{*}{ Private domestic Own. } & 0.000 & 1.000 & 0.000 \\
\hline & $(0.001)$ & $(0.001)$ & $(0.000)$ \\
\hline \multirow[t]{2}{*}{ Internal funds } & $-0.002^{\star * *}$ & $0.998^{\star * *}$ & $-0.001^{\star * *}$ \\
\hline & $(0.001)$ & $(0.001)$ & $(0.000)$ \\
\hline \multirow[t]{2}{*}{ Borrowed from bank } & 0.001 & 1.001 & 0.000 \\
\hline & $(0.001)$ & $(0.001)$ & $(0.000)$ \\
\hline \multirow[t]{2}{*}{ Borrowed Non-B } & $-0.005^{\star * *}$ & $0.994^{\star * *}$ & $-0.001^{\star * *}$ \\
\hline & $(0.002)$ & $(0.002)$ & $(0.000)$ \\
\hline \multirow[t]{2}{*}{ Credit Purchases } & $0.004^{\star * *}$ & $1.004^{* * *}$ & $0.001^{* * *}$ \\
\hline & $(0.001)$ & $(0.001)$ & $(0.000)$ \\
\hline \multirow[t]{2}{*}{ Firm size } & 0.018 & 1.018 & 0.004 \\
\hline & $(0.029)$ & $(0.029)$ & $(0.007)$ \\
\hline \multirow[t]{2}{*}{ Obstacle to Finance } & 0.010 & 1.010 & 0.002 \\
\hline & $(0.013)$ & $(0.013)$ & $(0.003)$ \\
\hline \multirow[t]{2}{*}{ MMs11 } & $0.191^{\star * *}$ & $1.210^{\star * *}$ & $0.046^{* * *}$ \\
\hline & $(0.048)$ & $(0.059)$ & $(0.012)$ \\
\hline \multirow[t]{2}{*}{ Foreign ownership } & 0.001 & 0.001 & 0.000 \\
\hline & $(0.001)$ & $(0.001)$ & $(0.000)$ \\
\hline \multirow[t]{2}{*}{ Government } & $-0.008^{* * *}$ & $0.992^{\star * *}$ & $-0.002^{\star * *}$ \\
\hline & $(0.002)$ & $(0.002)$ & $(0.001)$ \\
\hline \multirow[t]{2}{*}{ Firm Location } & $0.003^{* * *}$ & $1.002^{\star * *}$ & $0.001^{\star * *}$ \\
\hline & $(0.000)$ & $(0.000)$ & $(0.000)$ \\
\hline
\end{tabular}




\section{Continued}

Location Size

$\begin{array}{cccc}\text { Firm's Industry } & 0.000 & 1.000 & 0.000 \\ & (0.001) & (0.001) & (0.000) \\ \text { _cons } & -1.312^{* * *} & 0.269^{* * *} & \\ & (0.169) & (0.045) & \\ \text { Obs. } & 15525 & 15525 & \\ \text { McFadden } \mathrm{R}^{2} & 0.067 & \\ \text { Count } \mathrm{R}^{2} & 0.626 & \\ \text { P-value }^{2} & 0.391 & \end{array}$

Standard errors are in parenthesis. ${ }^{* *} p<0.01,{ }^{*} p<0.05,{ }^{*} p<0.1$.

Table 11. Results for significantly improved technology.

\begin{tabular}{|c|c|c|c|}
\hline New technology & Coefficients & Odds ratio & $\mathrm{dy} / \mathrm{dx}$ \\
\hline \multirow[t]{2}{*}{ Exporter } & $-0.004^{\star \star \star}$ & $0.996^{\star * *}$ & $-0.001^{\star * *}$ \\
\hline & $(0.001)$ & $(0.001)$ & $(0.000)$ \\
\hline \multirow[t]{2}{*}{ Email } & $0.351^{\star * *}$ & $1.421^{\star * *}$ & $0.087^{\star * *}$ \\
\hline & $(0.042)$ & $(0.060)$ & $(0.011)$ \\
\hline \multirow[t]{2}{*}{ Website } & $0.797^{\star * *}$ & $2.218^{\star * *}$ & $0.198^{\star * *}$ \\
\hline & $(0.044)$ & $(0.098)$ & $(0.011)$ \\
\hline \multirow[t]{2}{*}{ ISO } & $0.640^{\star * *}$ & $1.896^{* * *}$ & $0.159^{* * *}$ \\
\hline & $(0.049)$ & $(0.092)$ & $(0.012)$ \\
\hline \multirow[t]{2}{*}{ Top Manager female } & $-0.244^{* * *}$ & $0.783^{* * *}$ & $-0.061^{\star * *}$ \\
\hline & $(0.054)$ & $(0.043)$ & $(0.014)$ \\
\hline \multirow[t]{2}{*}{ Top Manager exp. } & $-0.022^{\star * *}$ & $0.978^{\star * *}$ & $-0.005^{* * *}$ \\
\hline & $(0.002)$ & $(0.002)$ & $(0.000)$ \\
\hline \multirow[t]{2}{*}{ Ln (Firm Age) } & $0.481^{\star * *}$ & $1.618^{\star * *}$ & $0.119^{* * *}$ \\
\hline & $(0.035)$ & $(0.057)$ & $(0.009)$ \\
\hline \multirow[t]{2}{*}{ Private domestic own. } & $0.002^{\star * *}$ & $1.002^{\star * *}$ & $0.001^{\star * \star}$ \\
\hline & $(0.001)$ & $(0.001)$ & $(0.000)$ \\
\hline \multirow[t]{2}{*}{ Internal funds } & $-0.005^{\star * *}$ & $0.995^{* * *}$ & $-0.001^{* * *}$ \\
\hline & $(0.001)$ & $(0.001)$ & $(0.000)$ \\
\hline \multirow[t]{2}{*}{ Borrowed from banks } & -0.000 & 1.000 & 0.000 \\
\hline & $(0.001)$ & $(0.001)$ & $(0.000)$ \\
\hline \multirow[t]{2}{*}{ Borrowed from Non-B } & -0.001 & 0.999 & 0.000 \\
\hline & $(0.002)$ & $(0.002)$ & $(0.000)$ \\
\hline \multirow[t]{2}{*}{ Credit Purchases } & 0.001 & 1.001 & 0.000 \\
\hline & $(0.001)$ & $(0.001)$ & $(0.000)$ \\
\hline
\end{tabular}




\section{Continued}

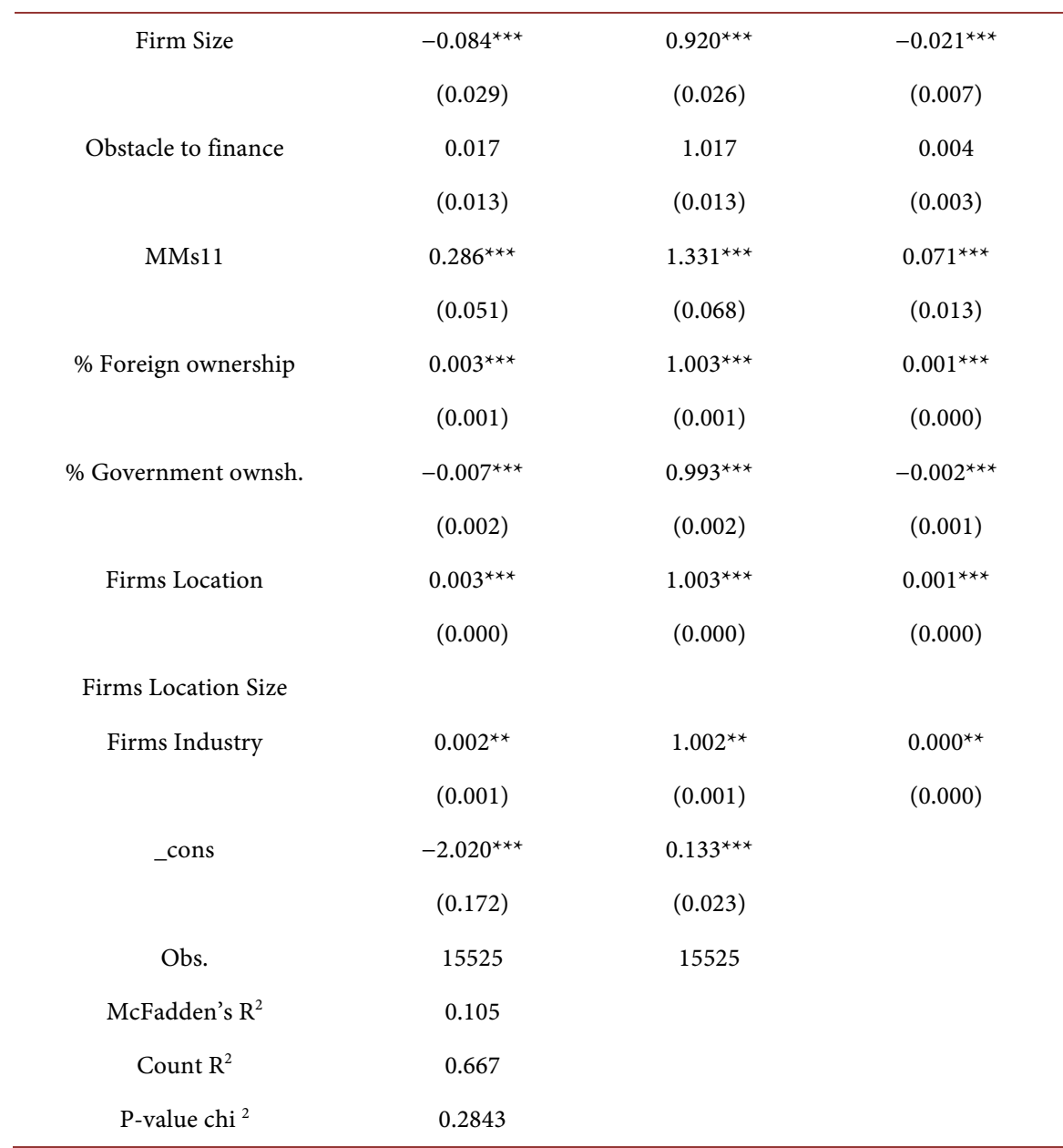

Standard errors are in parenthesis. ${ }^{* *} p<0.01,{ }^{* *} p<0.05,{ }^{*} p<0.1$.

top Female Manager, Mobile money usage (MMs1) are, all dummy variables that take the value 1 if the firm responded yes), firm age, top managers experience. Obstacles to access to firm finance, firm size are ordered variables, $\%$ of internal funding, $\%$ of Purchase credit, $\%$ of borrowing from banks, $\%$ of borrowing from non-bank, \% of government ownership, \% foreign ownership, \% private domestic ownership.

From the ordered logit model, where an index was created as the summation of firms with new product and firms with new technology (Index) as the dependent variable, the estimation results show that exporter firms, top female managers, top managers experience, internal funding, funds borrowed from non-banks, and the share of government ownership have positive and significant impact on firm innovation (new product). However, we also found that variables as emails, websites, ISO certification, MMs1, supply credit and private domestic ownership negatively impacts innovation. For instance, the odds of Index variable of innovative firm decrease by 0.73 when natural logarithm of age increases by 1 unit (i.e., a 1.46year increase in firm age). Similarly, the odds of Index variable innovative firm increase by 1.004 when then share of government owner- 
ship increases by 1 unit (i.e., a 1.984 decrease in government ownership).

From Table 12, the dependent variable is Index (a sum of New Product and New technology, it is an ordered variable). The independent variables are Exporter, Email, Website, ISO certification, top Female Manager, Mobile money

Table 12. Results for index (the sum of new product and new technology).

\begin{tabular}{|c|c|c|}
\hline Index & Coeff: & Odds ratio \\
\hline \multirow[t]{2}{*}{ Exporter } & $0.004^{\star * *}$ & $1.003^{* * *}$ \\
\hline & $(0.001)$ & $(0.001)$ \\
\hline \multirow[t]{2}{*}{ Email } & $-0.194^{* * *}$ & $0.823^{\star * *}$ \\
\hline & $(0.036)$ & $(0.029)$ \\
\hline \multirow[t]{2}{*}{ Website } & $-0.641^{* * *}$ & $0.527^{\star * *}$ \\
\hline & $(0.044)$ & $(0.022)$ \\
\hline \multirow[t]{2}{*}{ ISO } & $-0.615^{* * *}$ & $0.540^{\star * \star}$ \\
\hline & $(0.048)$ & $(0.026)$ \\
\hline \multirow[t]{2}{*}{ Top Manager female } & $0.163^{\star * *}$ & $1.177^{* * *}$ \\
\hline & $(0.045)$ & $(.053)$ \\
\hline \multirow[t]{2}{*}{ Top manager's exp. } & $0.014^{\star * *}$ & $1.014^{* * *}$ \\
\hline & $(0.002)$ & $(0.002)$ \\
\hline \multirow[t]{2}{*}{ Ln (Firm Age) } & $-0.313^{* * *}$ & $0.731^{\star * *}$ \\
\hline & $(0.029)$ & $(0.021)$ \\
\hline \multirow[t]{2}{*}{$\%$ Private domestic } & $-0.001^{\star}$ & $0.998^{*}$ \\
\hline & $(0.001)$ & $(0.001)$ \\
\hline \multirow[t]{2}{*}{ Internal funds } & $0.002^{* * *}$ & $1.002^{* * *}$ \\
\hline & $(0.001)$ & $(0.001)$ \\
\hline \multirow[t]{2}{*}{ Borrowed from banks } & -0.000 & 1.000 \\
\hline & $(0.001)$ & $(0.001)$ \\
\hline \multirow[t]{2}{*}{ Borrowed from Non-B } & $0.003^{* *}$ & $1.002^{* *}$ \\
\hline & $(0.001)$ & $(0.001)$ \\
\hline \multirow[t]{2}{*}{ Credit Purchases } & $-0.002^{\star}$ & $0.998^{*}$ \\
\hline & $(0.001)$ & $(0.001)$ \\
\hline \multirow[t]{2}{*}{ Firm Size } & -0.008 & 0.992 \\
\hline & $(0.027)$ & $(0.026)$ \\
\hline \multirow[t]{2}{*}{ Obstacle to Finance } & -0.010 & 0.990 \\
\hline & $(0.011)$ & $(0.011)$ \\
\hline \multirow[t]{2}{*}{ MMs11 } & $-0.311^{\star * *}$ & $0.733^{* * *}$ \\
\hline & $(0.043)$ & $(0.032)$ \\
\hline \multirow[t]{2}{*}{ Foreign ownership } & -0.001 & 0.999 \\
\hline & $(0.001)$ & $(0.001)$ \\
\hline
\end{tabular}




\section{Continued}

\begin{tabular}{ccc}
\hline Government ownership & $0.005^{* *}$ & $1.004^{* *}$ \\
Firm's Location & $(0.002)$ & $(0.002)$ \\
& $-0.003^{* * *}$ & $0.997^{* * *}$ \\
Firm's Location Size & $(0.000)$ & $(0.000)$ \\
Firm's Industry & & \\
& $-0.002^{* * *}$ & $0.998^{* * *}$ \\
/cut1 & $(0.001)$ & $(0.001)$ \\
& $-2.143^{* * *}$ & $-2.143^{* * *}$ \\
/cut2 & $(0.149)$ & $(0.149)$ \\
& $-0.492^{* * *}$ & $-0.492^{* * *}$ \\
Obs. & $(0.148)$ & $(0.148)$ \\
P-value Chi ${ }^{2}$ & 15525 & 15525 \\
\hline
\end{tabular}

Standard errors are in parenthesis. ${ }^{* *} p<0.01,{ }^{* *} p<0.05,{ }^{*} p<0.1$.

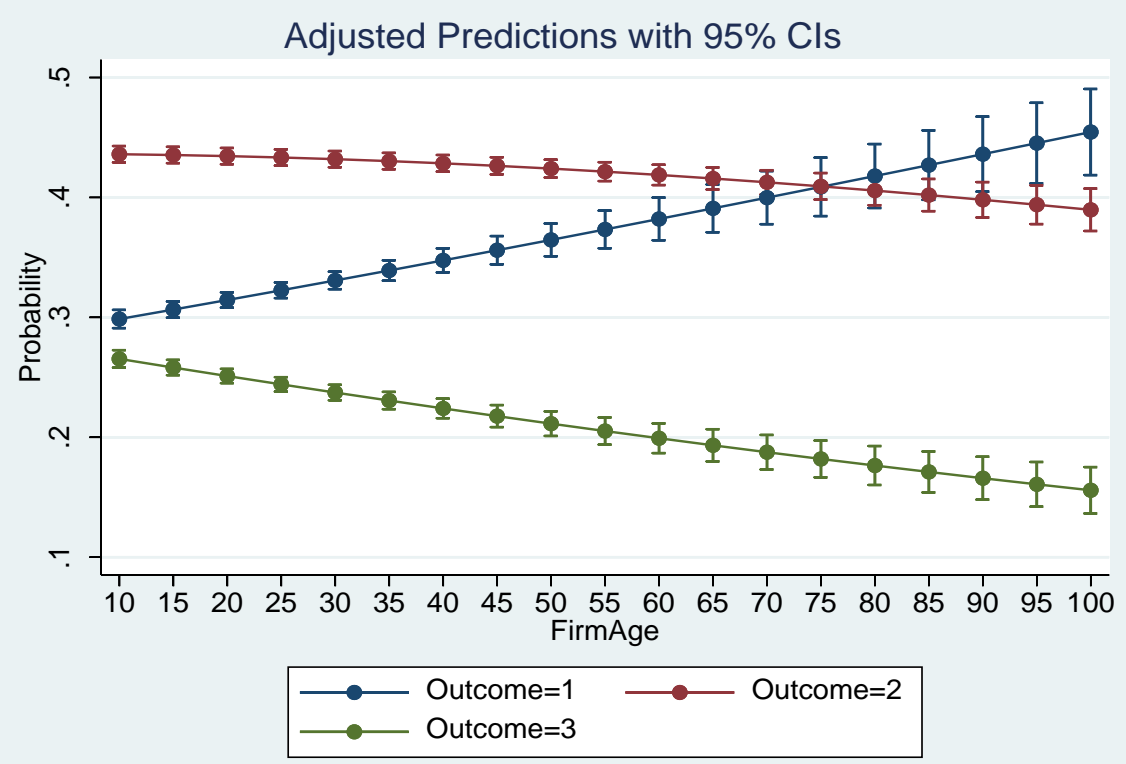

Note. (1) = high innovation, (2) = low innovation (3) = medium innovation.

Figure 4. Predicted probability of belonging to a given level of innovation versus firm age.

usage (MMs1) which are all dummy variables that take the value 1 if the firm responded yes, firm age, top managers experience. Obstacles to access to firm finance, firm size are ordered variables. \% of internal funding, \% of Purchase credit, $\%$ of borrowing from banks, $\%$ of borrowing from non-bank, $\%$ of government ownership, \% foreign ownership, \% private domestic ownership.

Figure 4 depicts the probability of belonging to an innovation level predicted 
by the ordered logit model against values of firm age 5, 10, 15, 25, 30, 35, 40 to 100 years for the sample. It can be seen that the probability of falling into innovation levels 2 , or 3 is negatively associated with firm age, whereas the probability of falling into innovation level 1 , is positively associated with firm age. This suggests that as an innovative grows older, the probability of belonging to the lower innovation category $((2)=$ low innovation $(3)=$ medium innovation) drops.

\section{Innovation in Africa and Low/Upper Middle-Income Countries}

According to the World Bank lending group, countries with GNI per capita of $\$ 1035$ or less in 2019 are lower-income countries, and countries with GNI per capita between $\$ 1036$ and $\$ 4045$ are middle-income countries. This classification means that all the countries in this sample fall under low-income countries except South Africa, Gabon, Namibia. Available data from the enterprise survey data suggests that between 2006 and 2019, 14.8\% of firms in Sub-Sahara Africa are using technology licensed from foreign companies, only $30.5 \%$ of firms have their own Web site, 56.9\% Percent of firms use email to interact with clients/suppliers, 71.6 Percent of firms whose new product/service is also new to the main market, $34.5 \%$ Percent of firms that introduced a process innovation, $16.1 \%$ Percent of firms that spend on R \& D form sample of over 24,000 manufacturing firms.

The latest Enterprise Survey is available for Benin in 2016 whilst it is more recent for other countries. On the question of whether a firm introduced a new product or new technology, $34.2 \%$, and $22.6 \%$ responded yes respectively. Only $14 \%$ of the firms in Benin responded yes to the question on spending on $\mathrm{R} \& \mathrm{D}$ in the past 3 years. It is also reported that $2.1 \%$ of firms in Benin are using technology licensed from foreign companies.

Similarly, the Enterprise Survey is available for Ghana in 2013 reports that, on the question of whether a firm introduced a new product or new technology, $52.5 \%$, and $69.1 \%$ responded yes respectively. Only $22.9 \%$ of the firms in Ghana responded yes to the question on spending on $\mathrm{R} \& \mathrm{D}$ in the past 3 years. It is also reported that $14.5 \%$ of firms in Ghana are using technology licensed from foreign companies.

We now turn to some upper-middle-income countries such as South Africa and Namibia. The 2014 Enterprise Survey reports that; 59.6\% of firms responded yes to the question of whether a firm introduced a new product, and $42.2 \%$ responded yes to the question on the introduction of a new technology. Only $14 \%$ of the firms in Namibia responded yes to the question on spending on R \& D in the past 3 years. It is also reported that $2.1 \%$ of firms in Namibia are using technology licensed from foreign companies. It is also reported in 2007 that $12.4 \%$ of firms in South Africa are using technology licensed from foreign companies. In relation to other middle-income countries such as Romania $12.4 \%$ of the sam- 
pled firm responded yes to the question on $\mathrm{R} \& \mathrm{D}$ expenditure whilst in Turkey $15.9 \%$ of the sampled firms spent on R \& D.

For a better demonstration of innovation initiatives, data is gathered on the Patent Cooperation Treaty (PCT) national phase entries) from the World Intellectual Property Organization (WIPO), http://www.wipo.int in 2021 on some African countries. The data showed that as on February 3, 2021, there were 3451, 1132, 3778, 304, 839, 1651, 37, 33,573 patent applications in Algeria, Angola, Egypt, Kenya, Madagascar, Morocco, Mozambique, and South-Africa, respectively. These numbers of applications are far less than the applications in other lower and upper-middle-income countries, such as, Chile (9570 patent applications) and Costa Rica (8191 patent applications).

In addition, the Global Innovation Index ranking, https://globalinnovationindex.org of 2020, ranks South Africa as the $60^{\text {th }}$ innovative country in the World with an innovation score of 32.67. other African countries in the ranking include Tunisia, Morocco, Kenya, Tanzania, Botswana, Rwanda, Egypt, Senegal, Namibia, Ghana, and Malawi scoring, 31.21, 28.97, $26.13,25.57,25.43,25.06,24.23,23.75,22.51,22.28$, and 21.44 respectively. These scores suggest that South Africa is the most competitive country in Africa within the upper-middle-income status along-side Botswana and Namibia (both scored below the global median score of 30.94). The only lower-middle-income country to have scored above the global median innovation score of 30.94 is Tunisia. In comparison, high-income countries such as Switzerland, Sweden, the U.S, U.K, Netherlands, and Demark are ranked as the most innovative countries in the index score $(66.08,62.47,60.56,59.78,58.76$ and 57.53 respectively). The most innovative country from the upper-middle-income bracket is China, scoring 53.28 and ranking $14^{\text {th }}$ in the World. Malaysia, Bulgaria, and Thailand are also other upper-middle-income countries that scored 42.42, 39.98, 36.68, and ranking 33,37 , and 44 respectively in the global innovation index ranking.

\section{Conclusions and Policy Implications}

Analyzing the data from the World Banks Enterprise Survey Indicators Database from 2009 to 2019 for 39 African countries, the study found that firm age, firm size, top managers experience, female top manager, ISO certification, exporter, email website, firm funding sources, firm ownership, and firm location are significant drivers of innovation in Africa. However, the statistics shown in Table 4, Table 5, Table 7, and Table 8 show that only $39.2 \%$ of the sample firms introduced new technology in the last three years, while $49.2 \%$ introduced new products in the last three years. In sharp contrast, we did not record a significant relationship between obstacles to access to finance and all the dependent variables (New Product, New Technology, and Index). We also found that only $19.6 \%$ of the sampled firms have ISO certification in the last three years. A summary of the level of innovation among firms as captured by Index, shows that only $31.7 \%$ of the firms fall within high innovation. This means that, only 
this percentage of firms spend on $\mathrm{R} \& \mathrm{D}$ and therefore are able to improve and introduce new products and new technology in the last three years.

We find the low innovation level in Africa is not surprising. Given the low levels of R \& D expenditure to GDP ratio, the number of patent applications, and the number of highly-qualified human capital per thousand labor force lag behind those of the United States and other upper-middle-income countries as shown in Figures 1-3. We again find one of the reasons for the low levels of firm innovation, aside from the low investment in $\mathrm{R} \& \mathrm{D}$, that there is a high concentration of the highly qualified human capital (researchers), mostly in higher learning institutions as opposed to public and private enterprises in Africa. Indeed, from Figure 2, we find a huge gap between development in FTE per 1000 in Sub-Sahara Africa and the US. While the FTE per 1000 in Sub-Sahara Africa was as low as 73, 84, and 91 in 2008, 2012, 2016, the USA recorded 3937, 4000, and 4256 during the same period. Similarly, from Figure 2, the FTE per 1000 in China (an Upper-Middle income country) is significantly higher than FTE per 1000 in Sub-Sahara Africa.

From the figures and regression analysis, the study suggests that, to salvage the low levels of firm innovation among African firms, it will be prudent to i) increase R \& D spending (the ratio of R \& D expenditure to GDP), ii) attract and incentivized highly qualified researcher's public and privative enterprises, not only into higher institutions of learning, and iii) incentivize and promote patent activities.

\section{Conflicts of Interest}

The authors declare no conflicts of interest regarding the publication of this paper.

\section{References}

Anokhin, S., \& Schulze, W. S. (2009). Entrepreneurship, Innovation, and Corruption. Journal of Business Venturing, 24, 465-476. https://doi.org/10.1016/j.jbusvent.2008.06.001

Ayyagari, M., Demirgüç-Kunt, A., \& Maksimovic, V. (2011). Firm Innovation in Emerging Markets: The Role of Finance, Governance, and Competition. Journal of Financial and Quantitative Analysis, 46, 1545-1580. https://doi.org/10.1017/S0022109011000378

Ayyagari, M., \& Maksimovic, V. (2007). Firm Innovation in Emerging Markets (Vol. 4157). World Bank Publications.

Bantel, K. A., \& Jackson, S. E. (1989). Top Management and Innovations in Banking: Does the Composition of the Top Team Make a Difference? Strategic Management Journal, 10, 107-124. https://doi.org/10.1002/smj.4250100709

Barasa, L., Knoben, J., Vermeulen, P., Kimuyu, P., \& Kinyanjui, B. (2017). Institutions, Resources and Innovation in East Africa: A Firm Level Approach. Research Policy, 46, 280-291. https://doi.org/10.1016/j.respol.2016.11.008

Barona-Zuluaga, B., Rivera-Godoy, J. A., Aguilera-Cifuentes, C. I., \& Garizado-Román, P. A. (2015). Financiación de la innovación en Colombia. Entramado, 11, 80-93. 
https://doi.org/10.18041/entramado.2015v11n1.21126

Blundell, R., Dearden, L., Meghir, C., \& Sianesi, B. (1999). Human Capital Investment: The Returns from Education and Training to the Individual, the Firm and the Economy. Fiscal Studies, 20, 1-23. https://doi.org/10.1111/j.1475-5890.1999.tb00001.x

Boschma, R. (2005). Proximity and Innovation: A Critical Assessment. Regional Studies, 39, 61-74. https://doi.org/10.1080/0034340052000320887

Chudnovsky, D., López, A., \& Pupato, G. (2006). Innovation and Productivity in Developing Countries: A Study of Argentine Manufacturing Firms' Behavior (1992-2001). Research Policy, 35, 266-288. https://doi.org/10.1016/j.respol.2005.10.002

Cooke, P., Uranga, M. G., \& Etxebarria, G. (1998). Regional Systems of Innovation: An Evolutionary Perspective. Environment and Planning A, 30, 1563-1584. https://doi.org/10.1068\%2Fa301563

Crespi, G., Tacsir, E., \& Zúñiga, P. (2011). Financial Constraints and Innovation Investment in Latin America: Evidence from Argentina, Chile and Uruguay. Georgia Institute of Technology.

Crespi, G., \& Zuniga, P. (2012). Innovation and Productivity: Evidence from Six Latin American Countries. World Development, 40, 273-290.

https://doi.org/10.1016/j.worlddev.2011.07.010

Custódio, C., Ferreira, M. A., \& Matos, P. (2019). Do General Managerial Skills Spur Innovation? Management Science, 65, 459-476. https://doi.org/10.1287/mnsc.2017.2828

De Jong, J. P., \& Vermeulen, P. A. (2006). Determinants of Product Innovation in Small Firms: A Comparison across Industries. International Small Business Journal, 24, 587-609. https://doi.org/10.1177\%2F0266242606069268

Fernandez, V. (2017). The Finance of Innovation in Latin America. International Review of Financial Analysis, 53, 37-47. https://doi.org/10.1016/j.irfa.2017.08.008

Franco, C., Marzucchi, A., \& Montresor, S. (2012). Absorptive Capacity, Innovation Cooperation and Human-Capital. Evidence from 3 European Countries (No. 05/2012). IPTS Working Papers on Corporate R\&D and Innovation.

Goedhuys, M. (2007). Learning, Product Innovation, and Firm Heterogeneity in Developing Countries: Evidence from Tanzania. Industrial and Corporate Change, 16, 269-292. https://doi.org/10.1093/icc/dtm003 https://academic.oup.com/icc/article-abstract/16/2/269/667057

Goedhuys, M., \& Veugelers, R. (2012). Innovation Strategies, Process and Product Innovations and Growth: Firm-Level Evidence from Brazil. Structural Change and Economic Dynamics, 23, 516-529. https://doi.org/10.1016/j.strueco.2011.01.004

Gorodnichenko, Y., Svejnar, J., \& Terrell, K. (2010). Globalization and Innovation in Emerging Markets. American Economic Journal: Macroeconomics, 2, 194-226. https://www.aeaweb.org/articles?id=10.1257/mac.2.2.194

Hall, B. H. (2002). The Financing of Research and Development. Oxford Review of Economic Policy, 18, 35-51. https://doi.org/10.1093/oxrep/18.1.35

Hall, B. H., \& Maffioli, A. (2008). Evaluating the Impact of Technology Development Funds in Emerging Economies: Evidence from Latin America. The European Journal of Development Research, 20, 172-198. https://doi.org/10.1080/09578810802060819

Jiménez-Jiménez, D., \& Sanz-Valle, R. (2011). Innovation, Organizational Learning, and Performance. Journal of Business Research, 64, 408-417.

https://doi.org/10.1016/j.jbusres.2010.09.010

Kamau, P., \& Munandi, I. (2009). Innovation in the Kenyan Clothing Sector and Its Im- 
pact on Employment and Poverty Reduction. Nairobi: Institute for Development Studies, University of Nairobi.

Laursen, K., Masciarelli, F., \& Prencipe, A. (2012). Regions Matter: How Localized Social Capital Affects Innovation and External Knowledge Acquisition. Organization Science, 23, 177-193. https://doi.org/10.1287/orsc.1110.0650

Lee, K., \& Kang, S.-M. (2007). Innovation Types and Productivity Growth: Evidence from Korean Manufacturing Firms. Global Economic Review, 36, 343-359. https://doi.org/10.1080/12265080701694512

Lee, N., Sameen, H., \& Cowling, M. (2015). Access to Finance for Innovative SMEs Since the Financial Crisis. Research Policy, 44, 370-380.

https://doi.org/10.1016/j.respol.2014.09.008

Li, H., \& Atuahene-Gima, K. (2001). Product Innovation Strategy and the Performance of New Technology Ventures in China. Academy of Management Journal, 44, 1123-1134.

Liu, X. (2015). Applied Ordinal Logistic Regression Using Stata: From Single-Level to Multilevel Modeling. Sage Publications.

Liu, X., \& Buck, T. (2007). Innovation Performance and Channels for International Technology Spillovers: Evidence from Chinese High-Tech Industries. Research Policy, 36, 355-366. https://doi.org/10.1016/j.respol.2006.12.003

Martín-de Castro, G., Delgado-Verde, M., Navas-López, J. E., \& Cruz-González, J. (2013). The Moderating Role of Innovation Culture in the Relationship between Knowledge Assets and Product Innovation. Technological Forecasting and Social Change, 80, 351-363. https://doi.org/10.1016/j.techfore.2012.08.012

McAdam, R., Reid, R., \& Shevlin, M. (2014). Determinants for Innovation Implementation at SME and Inter SME Levels within Peripheral Regions. International Journal of Entrepreneurial Behavior \& Research, 20, 66-90. https://doi.org/10.1108/IJEBR-02-2012-0025

McGuirk, H., \& Lenihan, H. (2013). Innovation and Human Capital: The Impact of Firm and Regional Factors on Innovative Human Capital. Working Paper, University of Limerick, Limerick.

Robson, P. J. A., Haugh, H. M., \& Obeng, B. A. (2009). Entrepreneurship and Innovation in Ghana: Enterprising Africa. Small Business Economics, 32, 331-350. https://doi.org/10.1007/s11187-008-9121-2

Romer, P. M. (1990a). Capital, Labor, and Productivity. Brookings Papers on Economic Activity. Microeconomics, 21, 337-367.

Romer, P. M. (1990b). Endogenous Technological Change. Journal of Political Economy, 98, S71-S102. https://doi.org/10.1086/261725

Roper, S., \& Love, J. H. (2006). Innovation and Regional Absorptive Capacity: The Labour Market Dimension. The Annals of Regional Science, 40, 437-447.

https://doi.org/10.1007/s00168-006-0068-4

Srholec, M. (2011). A Multilevel Analysis of Innovation in Developing Countries. Industrial and Corporate Change, 20, 1539-1569. https://doi.org/10.1093/icc/dtr024

Verdier, G., Kersting, E., \& Dabla-Norris, E., (2010). Firm Productivity, Innovation and Financial Development (Vol. 2010). IMF Working Papers, International Monetary Fund. https://doi.org/10.5089/9781451963250.001

Wang, C. C., \& Lin, G. C. S. (2013). Dynamics of Innovation in a Globalizing China: Regional Environment, Inter-Firm Relations and Firm Attributes. Journal of Economic Geography, 13, 397-418. https://doi.org/10.1093/jeg/lbs019 
Zuniga, P., \& Crespi, G. (2013). Innovation Strategies and Employment in Latin American Firms. Structural Change and Economic Dynamics, 24, 1-17.

https://doi.org/10.1016/j.strueco.2012.11.001 